\title{
PROSES SCAFFOLDING BERDASARKAN KESALAHAN PESERTA DIDIK DALAM PEMECAHAN MASALAH VOLUME BENDA PUTAR
}

\author{
Imam Fahcruddin ${ }^{*}$, I Made Sulandra ${ }^{2}$ \\ ${ }^{1}$ Sekolah Tinggi Ilmu Pelayaran Jakarta, ${ }^{2}$ Universitas Negeri Malang \\ * Corresponding Author. Email: imam_fahcruddin@dephub.go.id \\ Received: Tanggal Kirim; 25 Mei 2020: Revised: 15 September 2020 ; Accepted: 30 September 2020
}

\begin{abstract}
ABSTRAK
Salah satu penerapan integral tentu adalah menentukan volume benda putar. Beberapa kesalahan yang dialami perserta didik ketika menyelesaikan masalah volume benda putar yaitu kesalahan dalam menggambar benda putar dan kesalahan dalam memformulasikan volume benda putar dalam bentuk integral tentu. Penelitian ini bertujuan untuk mengetahui proses scaffolding yang diberikan kepada peserta didik berdasarkan kesalahan yang dialami ketika menyelesaikan masalah volume benda putar. Pemilihan subjek penelitian berdasarkan kelancaran komunikasi dan kemampuan peserta didik sehingga diperoleh tiga orang. Teknik pengumpulan data yang digunakan adalah think aloud. Dari hasil penelitian diperoleh beberapa kesalahan yang dialami keenam subjek penelitian dengan kemampuan awal yang berbeda yaitu menyederhanakan fungsi bernilai mutlak. Scaffolding yang diterapkan yaitu memberikan pertanyaan yang mengarahkan untuk mengingat dan menjelaskan definisi fungsi bernilai mutlak. Selain itu, semua subjek penelitian juga mengalami kesalahan dalam memformulasikan volume benda putar. Scaffolding yang diterapkan adalah memberikan pertanyaan untuk mengingatkan terkait konsep-konsep yang digunakan dalam memformu-lasikan volume benda putar. Kemudian, subjek penelitian dengan kemampuan rendah men-galami kesalahan dalam menentukan daerah yang dibatasi beberapa fungsi dan kesalahan dalam mengidentifikasi komponen-komponen yang digunakan untuk menentukan volume irisan benda putar. Scaffolding yang diterapkan adalah mengajak peserta didik untuk ber-kontribusi mencari petunjuk-petunjuk dalam menentukan daerah yang dibatasi beberapa fungsi.
\end{abstract}

Kata Kunci: Kesalahan, Volume Benda Putar, Scaffolding

\section{ABSTRACT}

One of the applied integral is calculating the volume of a solid of revolution. Some errors experienced by students when solving the problem of volume of a solid of revolution are errors in drawing rotating objects and errors in formulating the volume of rotating objects in the form of integrals. This study aims to determine the scaffolding process that is given to students based on errors experienced when resolving rotating objects volume problems. The selection of research subjects is based on the smooth communication and ability of students so as to get three people. The data collection technique used is think aloud. From the results of the study obtained several errors experienced by the three research subjects with different initial abilities that is to simplify the function of absolute value. Scaffolding that is applied is to provide questions that lead to remember and explain the definition of an absolute value function. In addition, all research subjects also experienced errors in formulating the volume of solid of revolution. The scaffolding that is applied is to provide questions to remind about the concepts used in formulating the volume of solid of revolution. Then, the research subject with low ability has an error in determining the area that is limited by several functions and an error in identifying the components used to determine the volume of solid of revolution. Scaffolding applied is inviting students to contribute to look for clues in determining areas that are limited by several functions. Keywords: error, volume of a solid of revolution, scaffolding

How to Cite: Fachruddin, I \& Sulandra, I, M. (2020). Proses Scaffolding Berdasarkan Kesalahan Peserta Didik Dalam Pemecahan Masalah Volume Benda Putar. Histogram: Jurnal Pendidikan Matematika, 4(2), $247 \quad-\quad 269$, doi: http://dx.doi.org/10.31100/histogram.v4i2.586

Permalink/DOI: http://dx.doi.org/10.31100/histogram.v4i2.586 


\section{Histogram: Jurnal Pendidikan Matematika, 4 (2), 2020 - 248 Imam Fahcruddin ${ }^{*}$, I Made Sulandra ${ }^{2}$}

\section{PENDAHULUAN}

Matematika merupakan ilmu yang mendasari perkembangan teknologi modern dan mempunyai peran penting dalam mengembangkan berbagai disiplin ilmu serta mengembangkan daya pikir manusia. Integral merupakan salah satu topik dalam matematika yang sangat penting dan banyak diterapkan secara luas pada cabang-cabang ilmu pengetahuan yang lain, misalnya pemodelan matematika, kontrol optimal (Fahcruddin, 2019), dan sistem dinamik (Fahcruddin, 2011). Topik integral mulai dipelajari pada jenjang pendidikan sekolah menengah atas atau yang sederajat dengan tiga kompetensi dasar, yaitu (1) Memahami konsep integral tak tentu dan integral tentu, (2) Menghitung integral tak tentu dan integral tentu dari fungsi aljabar dan fungsi trigonometri yang sederhana, (3) Menggunakan integral untuk menghitung luas daerah di bawah kurva dan volum benda putar (Sugiman, 2013). Lebih lanjut, beberapa jurusan di perguruan tinggi juga memberikan materi penerapan integral pada volume benda putar. Hal ini dirasa perlu guna kesesuaian antara pembelajaran teori serta praktek saat kerja nantinya (Pujireknati, 2019).

Berdasarkan studi pendahuluan yang peneliti lakukan pada salah satu lembaga pendidikan negeri ditemukan beberapa kesalahan yang dialami peserta didik ketika menyelesaikan masalah penerapan integral pada volume benda putar, misalnya kesalahan dalam menggambar grafik fungsi bernilai mutlak, kesalahan menentukan volume irisan benda putar serta kesalahan memformulasikan volume benda putar. Scaffolding perlu diberikan kepada peserta didik guna memperbaiki skema berpikir dalam memecahkan masalah matematis terutama benda putar (Wibawa, 2018). Dari studi pendahuluan tersebut, pengajar seharusnya melakukan upaya perbaikan kualitas pembelajaran di kelas, mampu bertindak sebagai motivator dan membimbing peserta didik selama proses pembelajaran berlangsung. Dalam hal ini, penerapan teori kognitif sosial yang dikembangkan oleh Vygotsky sangatlah tepat. Vygotsky memperkenalkan tentang pembelajaran sosial yaitu konsep tentang Zone of Proximal Development (ZPD) (Suardipa, 2020).

Menurut Vygotsky, peserta didik mempunyai dua tingkat perkembangan yang berbeda, yaitu: tingkat perkembangan aktual dan tingkat perkembangan potensial. Tingkat perkembangan aktual menentukan fungsi intelektual peserta didik saat ini dan kemampuannya untuk mempelajari sendiri hal-hal tertentu. Sedangkan tingkat perkembangan poten-sial didefinisikan sebagai tingkat yang dapat dicapai oleh peserta 


\section{Histogram: Jurnal Pendidikan Matematika, 4 (2), 2020 - 249 Imam Fahcruddin ${ }^{*}$, I Made Sulandra ${ }^{2}$}

didik dengan bantuan orang lain, misalnya guru, pengajar, atau teman sebaya. Sedangkan zona yang terletak di antara tingkat perkembangan aktual dan tingkat perkembangan potensial disebut sebagai ZPD (Suardipa, 2020).

Dengan tantangan dan bantuan yang tepat dari pengajar, atau teman sebaya, diharapkan peserta didik pada tingkat perkembangan potensial mampu mencapai ZPD, bahkan pada tingkat perkembangan aktual. Bantuan yang demikian ini dengan dukungan dinamis disebut scaffolding (Yohanes, 2010). Berdasarkan uraian tersebut perlu dilakukan penelitian tentang bagaimana proses scaffolding dalam membantu memperbaiki kesalahan peserta didik yang dialami ketika menyelesaikan masalah volume benda putar.

Dalam pembelajaran, kesalahan merupakan sesuatu yang menghambat peserta didik dalam menyelesaikan dengan benar persoalan yang dihadapi atau dalam memahami dengan cepat materi tertentu (Batanero et al., 2009). Untuk mengetahui apakah peserta didik mengalami kesalahan belajar matematika, maka peserta didik perlu diberikan masalah-masalah yang harus diselesaikan. Kesalahan peserta didik dapat diidentifikasi dari hasil penyelesaian masalah matematika secara tertulis yang dilanjutkan dengan pengajuan pertanyaan-pertanyaan lisan yang berkaitan dengan pemahaman peserta didik yang termuat dalam permasalahan tersebut (Kereh et al., 2013). Oleh karena itu, kesalahan yang dilakukan peserta didik perlu dicarikan solusi agar tidak menghambat dalam memahami materi matematika.

Dalam menyelesaikan suatu masalah dibutuhkan ketrampilan individu dan pemahaman konsep sebelumnya untuk dikembangkan dan diterapkan pada situasi baru (Krulik et al., 2003). Menurut Polya (1973), ada empat langkah dalam menyelesaikan masalah, yaitu (1) memahami masalah (understanding the problem), (2) memikirkan suatu rencana (devising a plan), (3) melaksanakan rencana (carrying out the plane), dan (3) memeriksa kembali (looking back).

Pada penelitian ini, masalah matematika yang dimaksud merupakan masalah penerapan integral dalam menentukan volume benda putar. Masalah penerapan integral pada volume benda putar juga dikaitkan dengan konsep-konsep yang dipelajari peserta didik sebelumnya, meliputi fungsi bernilai mutlak, dan integral tentu.

Ada empat ketrampilan yang dibutuhkan peserta didik dalam menyelesaikan masalah penerapan integral pada volume benda putar. Berikut ini disajikan tabel terkait hal tersebut (Mbokane et al., 2013). 


\section{Histogram: Jurnal Pendidikan Matematika, 4 (2), 2020 - 250}

Imam Fahcruddin $^{1 *}$, I Made Sulandra ${ }^{2}$

Tabel 1. Empat ketrampilan dalam menerapkan integral pada volume benda putar

\begin{tabular}{cll}
\hline No & \multicolumn{1}{c}{ Ketrampilan } & \multicolumn{1}{c}{ Keterangan } \\
\hline 1 & Menggambar grafik & $\begin{array}{l}\text { Peserta didik diharapkan dapat menggambar grafik } \\
\text { baik dengan menggunakan tabel atau menggunakan } \\
\text { karakteristik dari fungsi tersebut }\end{array}$ \\
& & $\begin{array}{l}\text { Peserta didik diharapkan dapat menentukan daerah } \\
\text { yang dibatasi beberapa fungsi, bentuk irisan benda }\end{array}$ \\
& $\begin{array}{l}\text { Menentukan daerah irisan } \\
\text { benda putar yang akan } \\
\text { dihitung volumenya }\end{array}$ & $\begin{array}{l}\text { putar yang digunakan untuk menghampiri volume } \\
\text { benda putar, dan volume irisan benda putar tersebut. }\end{array}$ \\
\hline 3 & Memformulasikan volume & Peserta didik diharapkan dapat menggunakan volume \\
& benda putar dalam bentuk & irisan benda putar untuk menghampiri volume benda \\
& integral tentu & putar secara keseluruhan sampai diperoleh bentuk \\
& & integral tentu. \\
\hline 3 & Menghitung hasil integral & Peserta didik diharapkan dapat menggunakan teknik \\
& suatu fungsi & integral untuk menyelesaikan hasil integral tentu dari \\
& & suatu fungsi yang diketahui kemudian menghitung \\
& & hasil integralnya \\
\hline
\end{tabular}

Kemudian langkah-langkah yang dilakukan untuk menyelesaikan masalah penerapan integral pada volume benda putar, diantaranya (Mbokane et al., 2013):

1. Menggambar grafik fungsi. Dengan menggambar grafik fungsi maka diperoleh grafik yang membatasi daerah pembentuk benda putar.

2. Menentukan daerah yang dibatasi fungsi. Dengan mengarsir daerah yang dibatasi fungsi maka diperoleh daerah pembentuk benda putar.

3. Menentukan volume irisan benda putar. Bentuk irisan benda putar tersebut diperlukan untuk mengetahui metode apa yang diterapkan. Lebih lanjut, volume irisan benda putar digunakan untuk menghampiri volume benda putar secara keseluruhan. Bentuk irisan benda putar bisa berupa cakram, cincin atau kulit tabung.

4. Memformulasikan volume benda putar dalam bentuk integral tentu. Dengan menjumlahkan sebanyak tak hingga volume irisan benda putar diperoleh bentuk integral tentu yang merepresentasikan volume benda putar.

5. Menghitung hasil integral tentu. Setelah mendapatkan bentuk integral tentu, langkah terakhirnya adalah menghitung hasil integralnya. Nilai yang diperoleh setelah menentukan hasil integral tentu merupakan volume benda putar.

Untuk mengatasi kesalahan peserta didik dalam menyelesaikan masalah tersebut, peneliti menggunakan scaffolding pada level 2 (explaining, reviewing, and restructuring) 


\section{Histogram: Jurnal Pendidikan Matematika, 4 (2), 2020 - 251 \\ Imam Fahcruddin $^{1 *}$, I Made Sulandra ${ }^{2}$}

dan level 3 (developing conceptual thinking) (Anghileri, 2006). Scaffolding diberikan jika peserta didik berada pada zona yang tidak terjangkau oleh peserta didik tersebut dan sedikit demi sedikit pendidik mengurangi bantuannya agar peserta didik mampu memahami dan mengerjakan tugas secara mandiri (Hartman, 2002).

Kemudian Roehler mengidentifikasi lima strategi yang digunakan pendidik dalam memberikan scaffolding kepada peserta didik (Bikmaz et al., 2010), yaitu;

1. Menawarkan penjelasan (Offering Explanation)

2. Mengajak peserta didik untuk berpartisipasi (Inviting Student Participation);

3. Memverifikasi dan mengklarifikasi pemahaman peserta didik (Verifying and Clarifying Student Understanding)

4. Memeragakan perilaku yang diinginkan (Modeling of desired behaviors)

5. Mengajak peserta didik untuk berkontribusi mencari petunjuk-petunjuk untuk mengerjakan soal (Inviting Students to Contribute Clues).

\section{METODE PENELITIAN}

Jenis penelitian yang digunakan adalah kualitatif. Subjek penelitian dipilih berdasarkan sampling bertujuan, yang diambil dengan memperhatikan kelancaran komunikasi peserta didik agar pengungkapan proses berfikir dan kesalahan yang dialami dapat dilakukan dengan baik. Kelancaran komunikasi yang dimaksud adalah kemampuan peserta didik dalam mengungkapkan gagasan dengan lengkap, akurat dan lancar (Asmana, 2018). Penentuan subjek penelitian diperoleh dari hasil rekomendasi pengajar dengan memperhatikan kelancaran komunikasi. Hal ini dilakukan untuk memudahkan dalam mengadaptasi berbagai cara dalam proses scaffolding ketika peserta didik melakukan kesalahan dalam memecahkan masalah yang diberikan.

Peneliti merencanakan untuk mengambil tiga sampel sebagai subjek penelitian berdasarkan tingkat kemampuan peserta didik, diantaranya; satu orang berkemampuan rendah (S1), satu orang berkemampuan sedang (S2), dan satu berkemampuan tinggi (S3). Penentuan subjek seperti ini diharapkan masing-masing subjek menjadi wakil yang dapat menggambarkan kondisi sebenarnya di lapangan. Kemudian, penetapan kategori kemampuan peserta didik didasarkan pada nilai ujian materi aplikasi integral pada volume benda putar. Hal ini dilakukan karena peserta didik sudah menerima penjelasan terkait fungsi bernilai mutlak, menggambar grafik, menentukan hasil integral tentu, dan penerapan 


\section{Histogram: Jurnal Pendidikan Matematika, 4 (2), 2020 - 252 Imam Fahcruddin ${ }^{*}$, I Made Sulandra ${ }^{2}$}

integral pada volume benda putar sehingga materi-materi tersebut masih tersimpan dalam memori peserta didik.

Teknik pengumpulan data yang digunakan adalah think aloud yaitu peserta didik mengungkapkan ide-ide yang dipikirkan menggunakan kalimat verbal dalam proses penyelesaian masalah matematika sehingga data yang didapat berupa kata-kata lisan dan hasil jawaban peserta didik (Yin, 2011). Adapun data yang digunakan dalam penelitian ini diperoleh berdasarkan lembar jawaban tertulis dan ungkapan verbal, yang terdiri dari:

1. Lembar jawaban ketiga subjek penelitian yang menggambarkan ditemukannya kesalahan ketika menyelesaikan masalah pada lembar tugas sebelum proses scaffolding dan setelah proses scaffolding.

2. Hasil rekaman suara dan gambar dari subjek penelitian ketika melakukan refleksi serta perbaikan selama proses scaffolding berlangsung. Hal ini dilakukan untuk menggambarkan langkah-langkah yang dilakukan subjek penelitian terutama ketika melakukan kesalahan dalam menyelesaikan masalah penerapan integral pada volume benda putar.

Instrumen penelitian yang digunakan berupa lembar tugas. Lembar tugas ini berisi soal yang memuat masalah penerapan integral pada volume benda putar. Lembar tugas terdiri dari dua lembar, lembar pertama berisi satu soal yang diberikan kepada peserta didik sebelum diberikan scaffolding, kemudian lembar kedua berisi satu soal yang diberikan kepada peserta didik setelah diberikan scaffolding. Hal ini dilakukan untuk mengetahui apakah peserta didik mengalami kesalahan setelah diberikan scaffolding. Proses scaffolding dikatakan berhasil apabila peserta didik tidak mengalami kesalahan pada saat menyelesaikan masalah pada lembar tugas kedua. Adapun masalah penerapan integral pada volume benda putar yang digunakan dalam penelitian ini sebagai berikut:

Lembar Tugas 1 . Tentukan volume benda putar yang terjadi jika daerah yang dibatasi fungsi $\quad f(x)=-|x-1|+1, g(x)=-x+2$ dan sumbu y diputar 3600 mengelilingi sumbu y.

Lembar Tugas 2. Tentukan volume benda putar yang terjadi jika daerah yang dibatasi fungsi

$f(x)=-|x-2|+1, g(x)=-|x-2|+2$ dan sumbu $\mathrm{x}$ diputar 3600 mengelilingi garis $y=-1$. 


\section{Histogram: Jurnal Pendidikan Matematika, 4 (2), 2020 - 253 Imam Fahcruddin ${ }^{1 *}$, I Made Sulandra ${ }^{2}$}

Lembar tugas telah divalidasi oleh dua orang ahli pada bidangnya, yang terdiri dari dosen matematika murni dan dosen pendidikan matematika. Validasi lembar tugas diarahkan pada kesesuaian masalah dengan tujuan penelitian, konstruksi masalah, dan kesesuaian bahasa yang digunakan. Kriteria yang digunakan dalam konstruksi masalah diantaranya (1) kalimat tidak menimbulkan penafsiran ganda, (2) batasan yang diberikan cukup cukup untuk memecahkan masalah, (3) fakta yang diminta dalam masalah dirumuskan dengan jelas (3) konsep yang digunakan untuk menyelesaikan masalah sudah pernah dipelajari atau dikenal sebelumnya. Kriteria kesesuaian bahasa diantaranya (1) penggunaan bahasa sesuai dengan kaidah bahasa yang baik dan benar, (2) soal yang diberikan jelas dan tidak menimbulkan penafsiran ganda, dan (3) rumusan masalah menggunakan kata-kata yang dikenal peserta didik. Dari hasil validasi oleh validator diperoleh rata-rata nilai lebih dari sama dengan tiga sehingga lembar tugas dikatakan valid.

Secara umum, tahapan-tahapan dalam penelitian ini disajikan dalam gambar berikut ini.

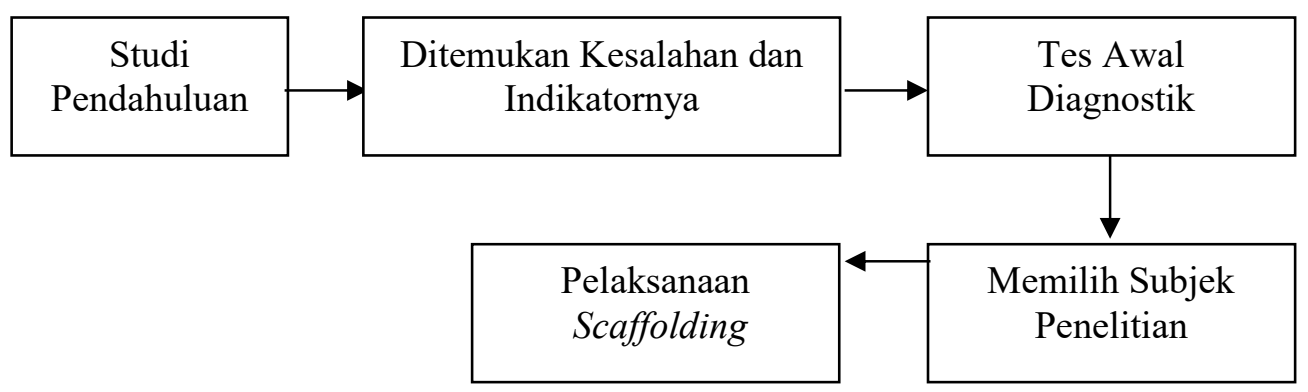

Gambar 1. Tahap-Tahap Penelitian

Peneliti membuat lembar tugas untuk studi pendahuluan. Peneliti melaksanakan studi pendahuluan dengan memberikan lembar tugas ke peserta didik kelas A sebanyak 30 orang. Dalam pelaksanaanya, peserta didik diminta untuk menyelesaikan soal-soal dalam lembar tugas secara individu dan tutup buku serta menuliskan langkah-langkah kerja secara jelas. Peneliti memeriksa hasil pekerjaan peserta didik dan menyusun indikatorindikator kesalahan berdasarkan hasil pekerjaan peserta didik.

Pada tahap tes diagnostik dan pemilihan subjek penelitian, peneliti memilih peserta didik kelas B untuk diberikan lembar tugas. Sebanyak 30 orang dijadikan subjek tes diagnostik. Dari analisis hasil tes diagnostik ditetapkan peserta didik yang tidak dipilih menjadi calon subjek penelitian adalah peserta didik yang sudah dapat menjawab dengan benar dan peserta didik yang tidak menjawab sama sekali lembar tugas. Sebaliknya, peserta 
Histogram: Jurnal Pendidikan Matematika, 4 (2), 2020 - 254 Imam Fahcruddin $^{1 *}$, I Made Sulandra ${ }^{2}$

didik yang belum dapat menjawab dengan benar untuk masalah yang diberikan dipertimbangkan untuk dipilih sebagai subjek penelitian. Diantara peserta didik yang belum dapat menjawab dengan benar dipilih lagi peserta didik yang mampu berkomunikasi dengan lancar dan dapat mengungkapkan gagasannya selama scaffolding.

Untuk tahap pelaksanaan scaffolding dilakukan peneliti pada saat wawancara kepada peserta didik yang ditetapkan sebagai subjek penelitian. Subjek penelitian diberi kesempatan untuk melakukan refleksi terhadap apa yang telah dikerjakannya, kemudian peneliti mengajaknya untuk berdiskusi tentang apa yang telah ia kerjakan. Adapun proses scaffolding yang digunakan dalam penelitian ini disajikan dalam gambar berikut ini.

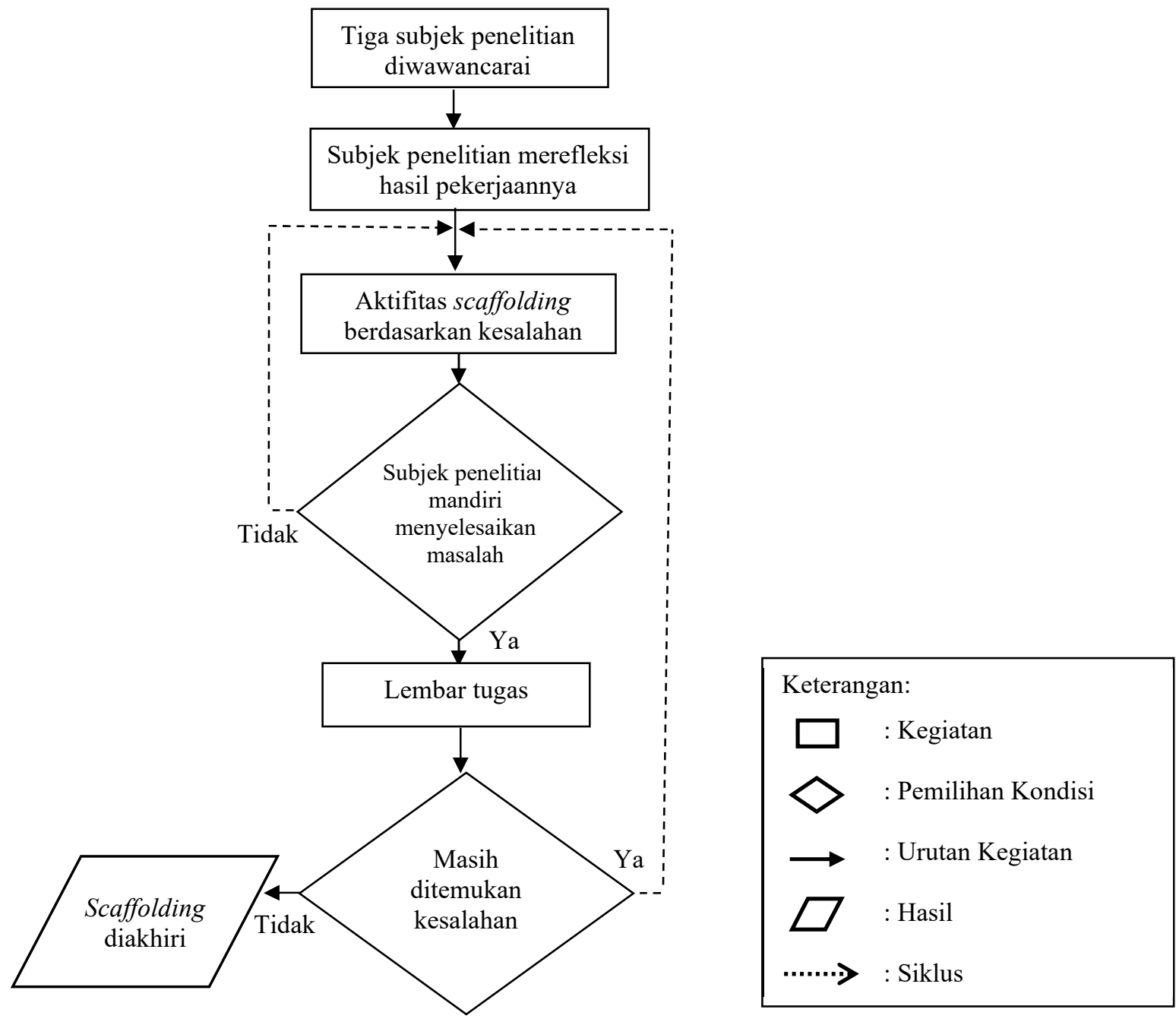

Gambar 2. Diagram Tahap Pelaksanaan Scaffolding 


\section{Histogram: Jurnal Pendidikan Matematika, 4 (2), 2020 - 255 Imam Fahcruddin ${ }^{1 *}$, I Made Sulandra ${ }^{2}$}

\section{HASIL DAN PEMBAHASAN}

Dari ketiga subjek penelitian diperoleh data kesalahan dan proses scaffolding dalam menyelesaikan lembar tugas pertama. Kesalahan-kesalahan yang dialami peserta didik dideskripsikan untuk masalah yang telah diberikan pada lembar tugas pertama. Kemudian peserta didik diberikan waktu untuk mengerjakan kembali lembar tugas tersebut dengan didampingi oleh peneliti. Proses scaffolding dilakukan peneliti pada saat peserta didik mengalami kesalahan dalam mengerjakan lembar tugas. Selanjutnya digambarkan struktur berpikir peserta didik pada saat proses scaffolding dalam menyelesaikan lembar tugas.

\section{PROSES SCAFFOLDING S1}

Berikut disajikan jawaban S1 dalam menyelesaikan lembar tugas 1 sebelum proses scaffolding.

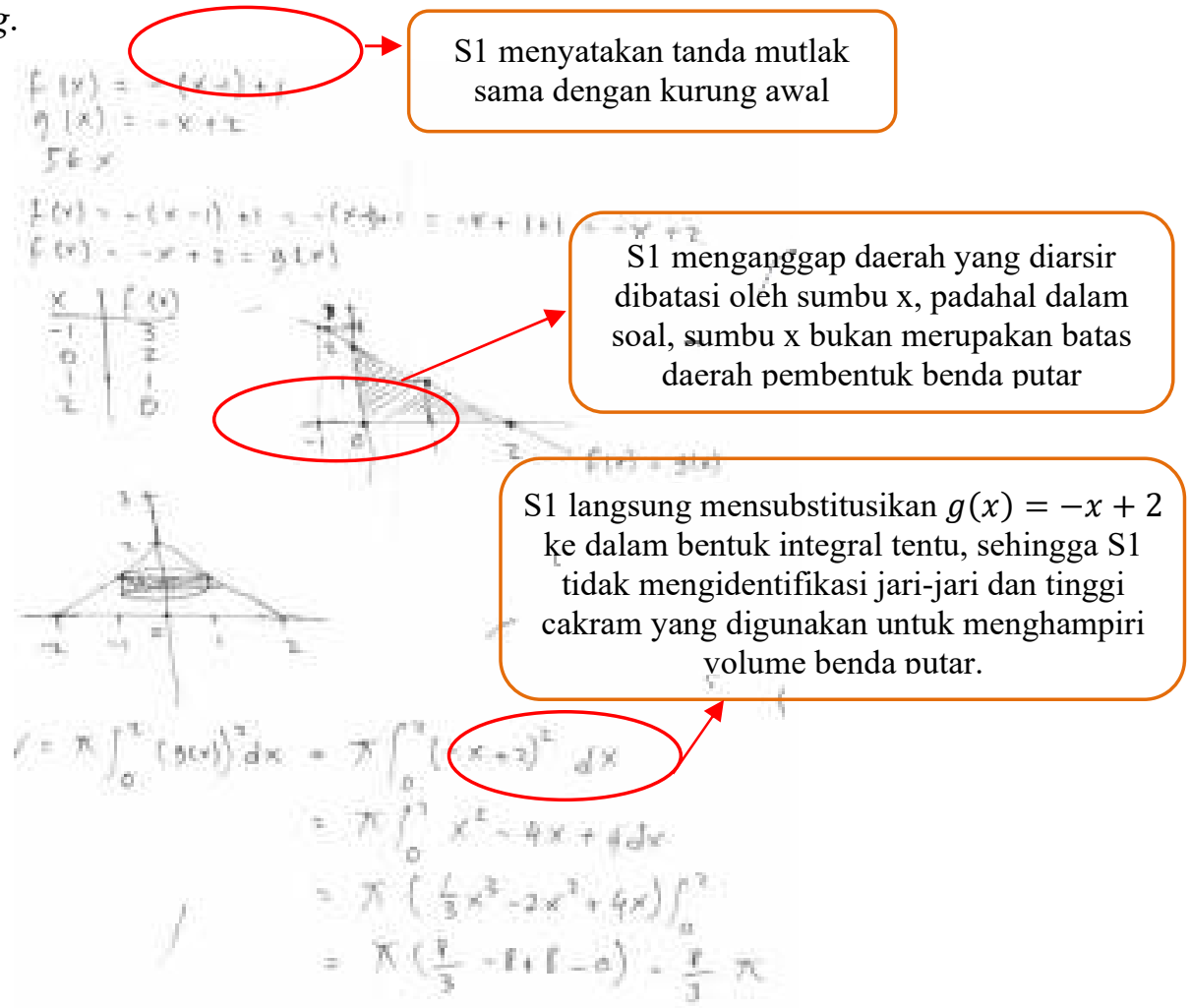

Gambar 3. Penyelesaian lembar tugas 1 oleh S1 sebelum proses scaffolding

Dalam menyelesaikan lembar tugas, sebagian struktur masalah sudah diketahui S1. Sebelum proses scaffolding hanya terjadi proses memahami masalah dan merencanakan masalah yang tidak lengkap serta melaksanakan rencana yang diawali dengan asumsi yang tidak benar. S1 menggunakan pengetahuan yang dimiliki untuk menyelesaikan masalah, 


\section{Histogram: Jurnal Pendidikan Matematika, 4 (2), 2020 - 256 Imam Fahcruddin $^{1^{*}}$, I Made Sulandra ${ }^{2}$}

meskipun pengetahuan yang dimiliki tidak lengkap. Namun demikian, tidak berarti S1 tidak mampu menyelesaikan masalah tersebut. Mungkin saja, S1 belum menggunakan pengetahuan yang dimiliki secara optimal.

Dari hasil wawancara dan mengamati hasil pekerjaan S1 diperoleh beberapa kesalahan yang dilakukan S1 ketika menyelesaikan lembar tugas 1, diantaranya; S1 melakukan kesalahan dalam menyederhanakan fungsi bernilai mutlak, S1 melakukan kesalahan dalam menggambar grafik fungsi bernilai mutlak, dan S1 melakukan kesalahan dalam memformulasikan volume benda putar dalam bentuk integral tentu.

Sebelum proses scaffolding dimulai, peneliti memberikan kesempatan kepada S1 untuk mengerjakan kembali lembar tugas 1 dengan didampingi oleh peneliti. Peneliti mengamati penyelesaian yang ditulis $\mathrm{S} 1$, kemudian proses scaffolding dilakukan pada saat S1 melakukan kesalahan dalam menyelesaikan lembar tugas tersebut. Proses scaffolding yang pertama dilakukan peneliti kepada S1 ketika S1 melakukan kesalahan dalam menyederhanakan fungsi bernilai mutlak. Kesalahan ini dialami S1 ketika menyesaikan lembar tugas 1.

Pada saat wawancara, S1 menyatakan tidak memahami definisi fungsi bernilai mutlak sehingga berasumsi menyamakan tanda kurung awal dengan tanda mutlak. Scaffolding yang diterapkan adalah mengajak peserta didik untuk berpartisipasi menyelesaikan permasalahan menyederhanakan fungsi bernilai mutlak dan memverifikasi serta mengklarifikasi pemahaman peserta didik tentang fungsi bernilai mutlak. Scaffolding yang diberikan berupa pertanyaan untuk mengarahkan peserta didik agar mengingat dan menjelaskan kembali definisi fungsi bernilai mutlak $|\mathrm{x}|$, kemudian menginstruksikan peserta didik untuk menyederhanakan fungsi bernilai mutlak lainnya seperti yang dilakukan pada saat menyederhanakan $|\mathrm{x}|$. Berikut ini disajikan wawancara peneliti ketika proses scaffolding dalam menyederhanakan fungsi bernilai mutlak.

$\mathrm{P}$ : Apa yang kamu ketahui tentang fungsi bernilai mutlak?

S1: Fungsi yang selalu bernilai positif Pak

$\mathrm{P}$ : Apakah selalu bernilai positif?

S1: (terdiam sebentar) Boleh nol Pak, jadi bisa nol atau positif

$\mathrm{P}:$ Berarti $|x|$ sama dengan apa?

S1: Sama dengan $x$ untuk $x$ yang nol atau positif

$\mathrm{P}$ : Kalau $x$ nya negatif bagaimana?

S1: $x$ negatif, (terdiam berpikir) berarti $|x|=-x$

Akhirnya S1 dapat menuliskan definisi fungsi bernilai mutlak dengan benar, seperti tampak pada gambar berikut. 


\section{Histogram: Jurnal Pendidikan Matematika, 4 (2), 2020 - 257 Imam Fahcruddin $^{1^{*}}$, I Made Sulandra ${ }^{2}$}

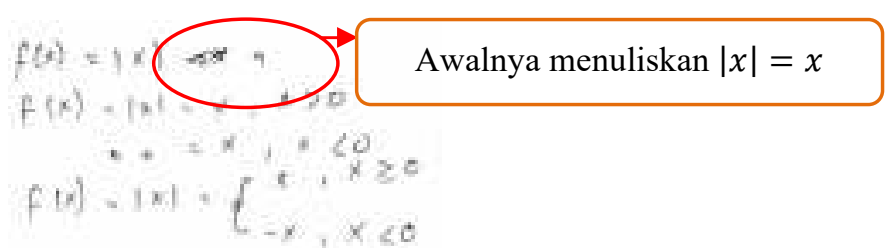

Gambar 4. Penyelesaian S1 ketika menyederhanakan $|x|$ setelah scaffolding

Kemudian peneliti meminta S1 untuk menyederhanakan $-|x-1|+1$ seperti yang S1 lakukan ketika menyederhanakan $|x|$.

$\mathrm{P}:$ Perhatikan jawaban kamu ketika menyederhanakan $|x|$. Bandingkan dengan $-|x-1|+1$. Apakah ada yang tidak sesuai?

S1: (terdiam lama) Oh, Benar Bapak, seharusnya yang atas tetap minus

$\mathrm{P}$ : Baik, sekarang kenapa saat menyederhanakan $|x|, x$ dibagi menjadi dua kasus, $x$ lebih dari sama dengan nol dan $x$ kurang dari nol?

S1: Karena yang dimutlakkan $x$, jadi ketika $x$ lebih dari sama dengan nol, $|x|=x$, terus untuk $x$ kurang dari nol, agar nilainya non negatif maka $|x|=-x$.

$\mathrm{P}:$ Betul, kalau yang disederhanakan $-|x-1|+1$, apakah seperti itu hasilnya?

S1: Tidak Bapak, seharusnya $x-1 \geq 0$ atau $x-1<0$.

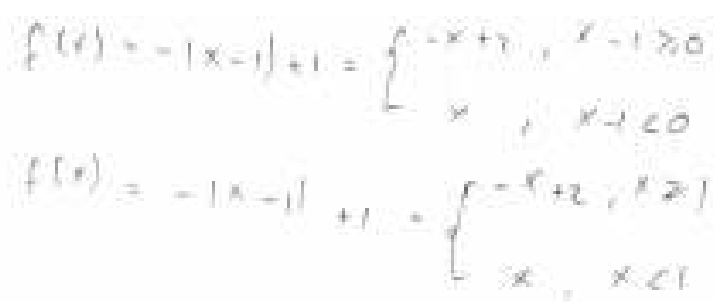

Gambar 5. Penyelesaian S1 ketika menyederhanakan $-|x-1|+1$ setelah scaffolding

Kedua, kesalahan dalam menentukan daerah yang dibatasi beberapa fungsi. Kesalahan ini dialami oleh subjek penelitian dengan kemampuan rendah. Hal ini terjadi karena memahami bahwa daerah yang dibatasi fungsi merupakan daerah yang dibentuk oleh irisan daerah dibawah kurva. Strategi scaffolding yang diterapkan adalah mengajak peserta didik untuk berkontribusi mencari petunjuk-petunjuk dalam menentukan daerah yang dibatasi beberapa fungsi. Proses scaffolding berupa pertanyaan yang mengarahkan peserta didik mengingat daerah yang diarsir dibatasi oleh fungsi apa saja dan mencermati batas-batas tersebut. Berikut ini disajikan wawancara peneliti pada saat proses scaffolding.

$\mathrm{P}$ : Perhatikan gambar ini, apakah daerah yang di arsir merupakan daerah yang dibatasi fungsi $g(x)$ dan sumbu $y$ ?

S1: Iya Pak

$\mathrm{P}$ : Coba dicermati kembali, batas-batasnya yang mana?

S1: Ini Pak (sambil mengamati batas-batas daerah yang diarsir, yaitu grafik fungsi $f(x)$ dan $g(x))$

$\mathrm{P}$ : Baik, sekarang daerah yang dibatasi garis tersebut yang mana?

S1: Oh, yang ini Bapak 


\section{Histogram: Jurnal Pendidikan Matematika, 4 (2), 2020 - 258 Imam Fahcruddin ${ }^{*}$, I Made Sulandra ${ }^{2}$}

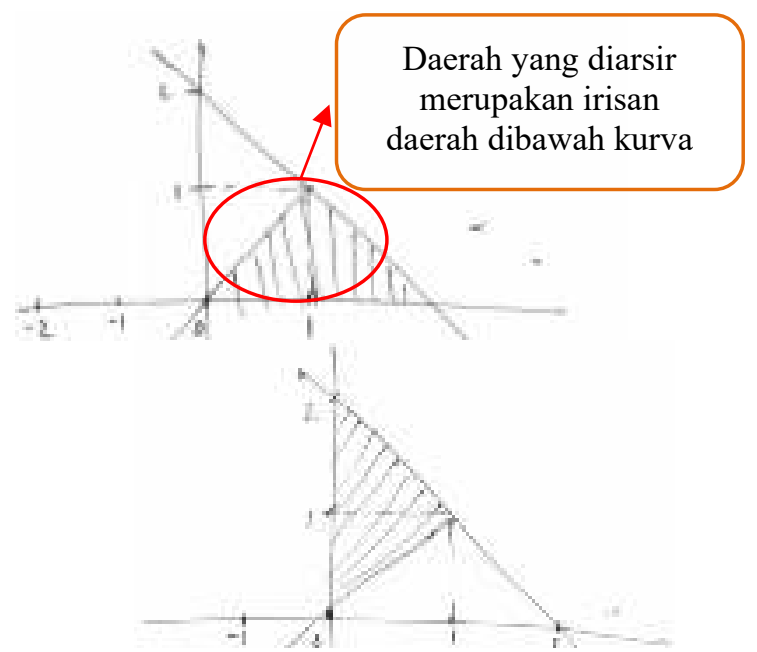

(a)

Gambar 6. Penyelesaian masalah 1 ketika S1 menentukan daerah yang dibatasi fungsi $f(x), g(x)$ sebelum diberi scaffolding (a) dan sesudah diberi scaffolding (b)

Kemudian S1 membuat kulit tabung yang digunakan untuk menghampiri volume benda putar tersebut. Namun, S1 berhenti mengerjakan pada saat menentukan tinggi kulit tabung, S1 terdiam dan bingung menentukan tingginya. Oleh karena itu, peneliti memberikan arahan sebagai berikut.

$\mathrm{P}$ : Tentukan yang mana tinggi kulit tabung?

S1: Ini bapak (memberi garis untuk menunjukkan tinggi kulit tabung)

$\mathrm{P}$ : Baik, misalkan ini adalah $x_{i}$, (jari tangan peneliti menunjuk letak titik $x_{i}$ ) berapa tingginya?

S1: (lama mengamati tinggi kulit tabung) $O h,-x_{i}+2$ dikurangi $x_{i}$ Pak

$\mathrm{P}: x_{i}$ mulai dari mana, sampai mana?

S1: Dari nol sampai satu Bapak

Setelah menentukan volume kulit tabung, S1 berhenti mengerjakan tahap selanjutnya, yaitu merumuskan volume benda putar. S1 tidak mengerti harus memulai dari mana. Tampak ekspresi wajah S1 yang berpikir keras bagaimana memformulasikan volume benda putar.

Kemudian peneliti memberikan arahan sebagai berikut.

P : Bagaimana cara kamu menentukan volume benda putar?

S1: Dihampiri dengan kulit tabung Bapak

$\mathrm{P}:$ Bagaimana cara menghampirinya?

S1: (terdiam lama, berpikir) Kulit tabungnya dibuat sangat banyak, kemudian dijumlahkan

$\mathrm{P}:$ Bagaimana menuliskannya?

S1: (Melihat keatas, memikirkan konsep yang harus digunakan) Menggunakan sigma Bapak, misalkan dari 1 sampai $n$ 
Histogram: Jurnal Pendidikan Matematika, 4 (2), 2020 - 259

Imam Fahcruddin $^{1 *}$, I Made Sulandra ${ }^{2}$

$\mathrm{P}:$ Baik, silahkan ditulis

$\mathrm{P}$ : Nah, kulit tabungnya dibuat sampai berapa?

S1: Sampai tak hingga Bapak, menggunakan limit n menuju tak hingga sehingga dapat bentuk integral tentu

Kemudian S1 melanjutkan mengerjakan lembar tugas 1 tanpa melakukan kesalahan seperti tampak pada gambar berikut.

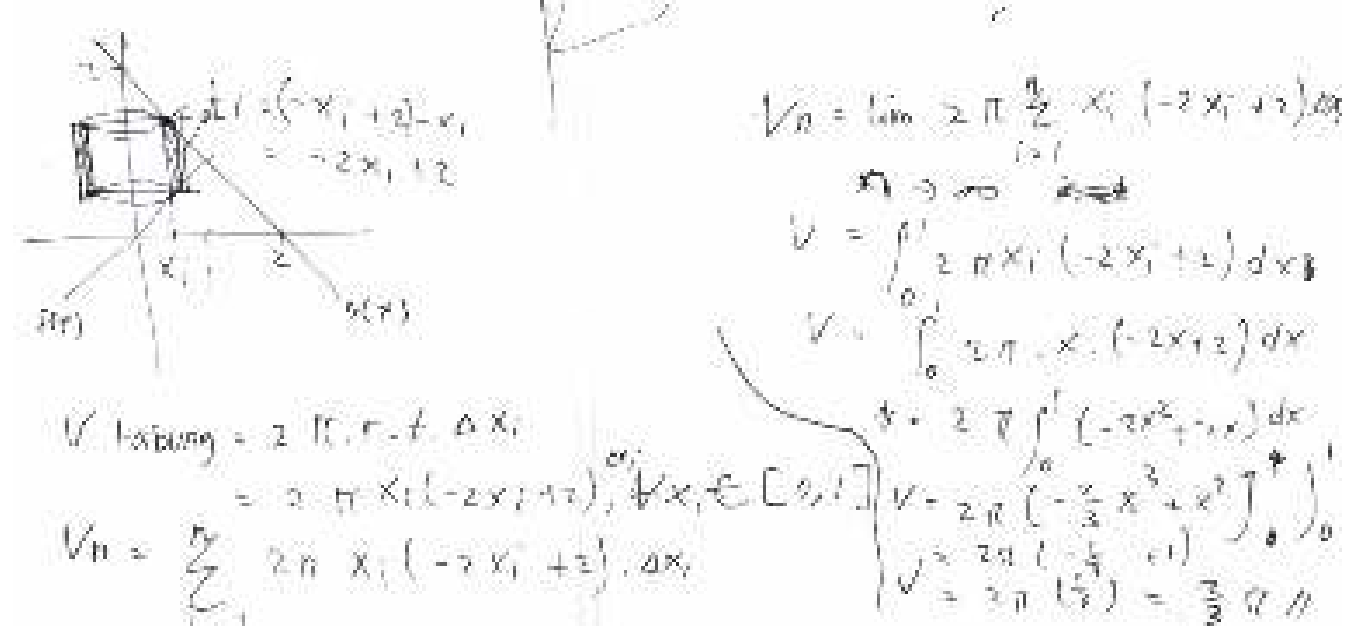

Gambar 7. Penyelesaian S1 ketika memformulasikan volume benda putar

Lebih lanjut, peneliti meminta S1 untuk mengerjakan lembar tugas 2. Keefektifan proses scaffolding ditunjukkan dengan tidak ditemukannya kesalahan-kesalahan yang dilakukan S1 ketika mengerjakan lembar tugas 2. S1 mampu memahami masalah secara lengkap dan membuat perencanaan dengan baik serta melaksanakan rencana dengan benar sehingga memperoleh jawaban yang benar.

\section{PROSES SCAFFOLDING S2}

Selanjutnya, jawaban S2 dalam menyelesaikan lembar tugas 1 sebelum proses scaffolding disajikan dalam gambar berikut.

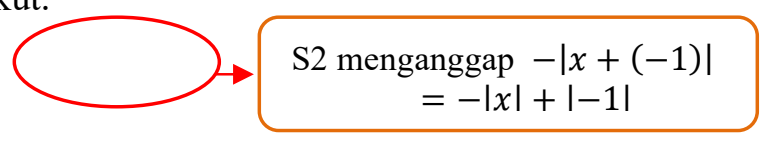


Histogram: Jurnal Pendidikan Matematika, 4 (2), 2020 - 260 Imam Fahcruddin ${ }^{*}$, I Made Sulandra ${ }^{2}$

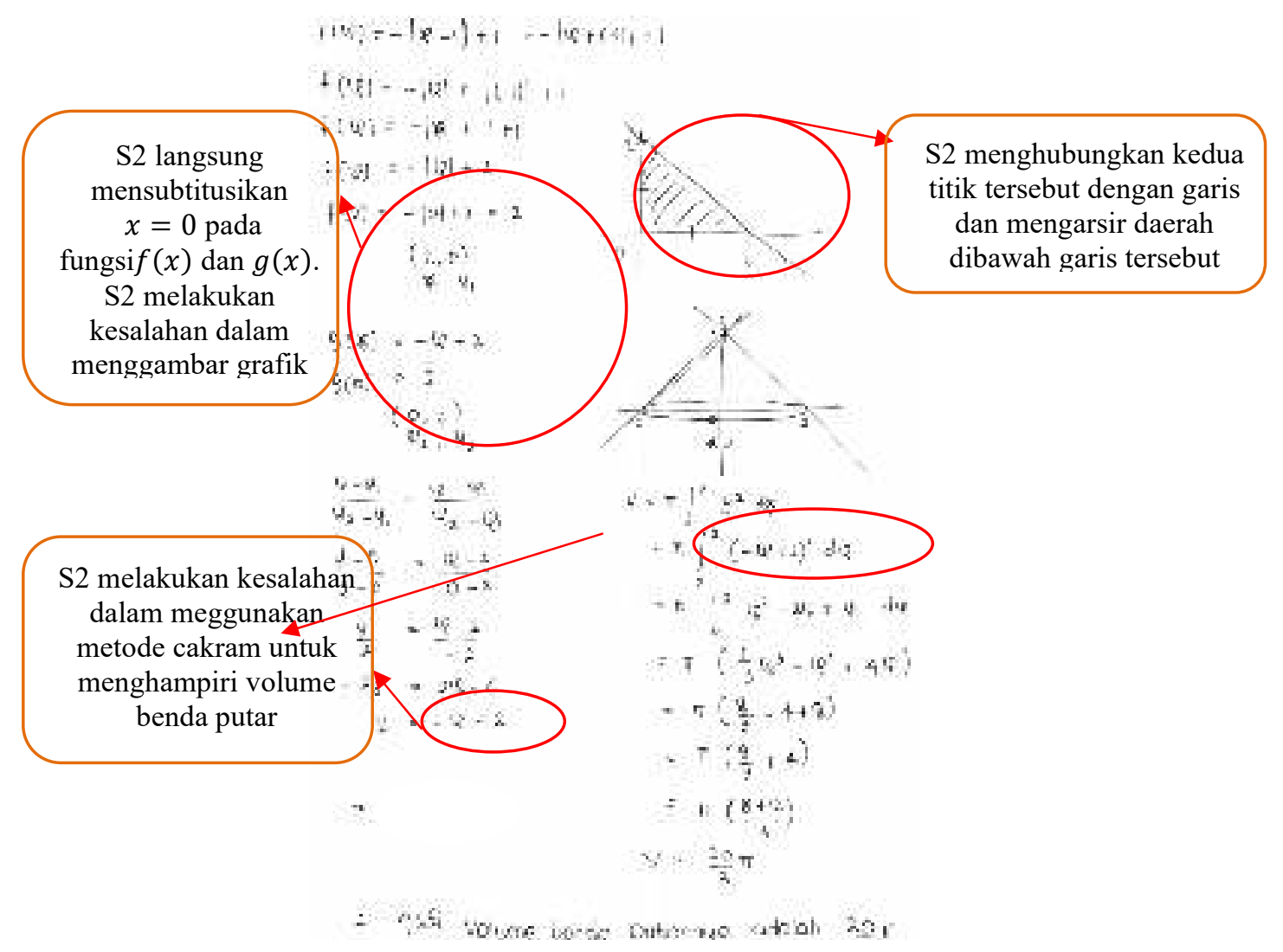

Gambar 8. Penyelesaian lembar tugas 1 oleh S2 sebelum proses scaffolding

Dalam menyelesaikan lembar tugas 1, sebagian struktur masalah sudah diketahui S2. Sebelum proses scaffolding terjadi proses memahami masalah dan merencanakan masalah yang tidak lengkap serta melaksanakan rencana yang diawali dengan asumsi yang tidak benar. S2 menggunakan pengetahuan yang dimiliki untuk menyelesaikan masalah, meskipun pengetahuan yang dimiliki tidak lengkap. Lebih lanjut, S2 tidak memeriksa kembali jawaban yang ditemukan.

Dari hasil wawancara dan mengamati hasil pekerjaan S2 diperoleh beberapa kesalahan yang dialami S2 dalam mengerjakan lembar tugas 1, diantaranya; S2 melakukan kesalahan dalam menyederhanakan fungsi bernilai mutlak, S2 melakukan kesalahan dalam menggambar grafik fungsi bernilai mutlak, dan S2 melakukan kesalahan dalam memformulasikan volume benda putar dalam bentuk integral tentu.

Pada saat wawancara, S2 menyatakan kurang memahami fungsi bernilai mutlak sehingga berasumsi $-|x+(-1)|=-|x|+|-1|$. Scaffolding yang diberikan berupa pertanyaan untuk mengingat kembali definisi fungsi bernilai mutlak $|\mathrm{x}|$, kemudian 


\section{Histogram: Jurnal Pendidikan Matematika, 4 (2), 2020 - 261 Imam Fahcruddin ${ }^{*}$, I Made Sulandra ${ }^{2}$}

menginstruksikan peserta didik untuk menyederhanakan fungsi bernilai mutlak lainnya seperti yang dilakukan pada saat menyederhanakan $|x|$.

Setelah menyederhanakan fungsi $f(x)=-|x-1|+1$, S2 kurang teliti dalam menyederhanakan bentuk $-(-(x-1)+1)$ dan kurang cermat dalam menentukan batas nilai $x$, seperti tampak pada gambar berikut.

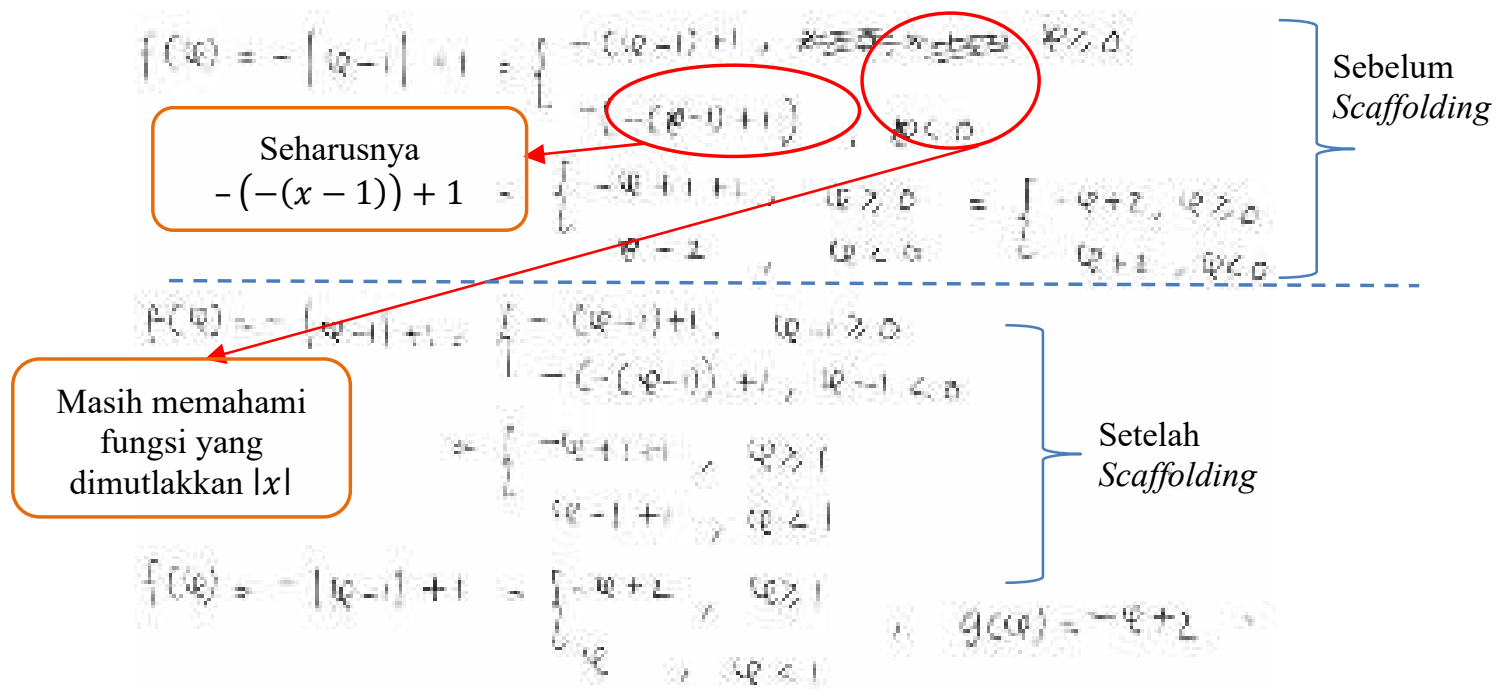

Gambar 9. Penyelesaian lembar tugas 1 ketika S2 menyederhanakan $-|x-1|+1$

Scaffolding yang diberikan yaitu memverifikasi dan mengklarifikasi pemahaman peserta didik tentang penjabaran fungsi bernilai mutlak dengan cara memberi perintah untuk mencermati kembali penjabaran fungsi bernilai mutlak oleh S2 dengan memperhatikan fungsi yang ada didalam tanda mutlak. Akhirnya, S2 mengerjakan kembali penjabaran fungsi bernilai mutlak tanpa melakukan kesalahan, seperti tampak pada Gambar 3.

Selanjutnya S2 menggambar grafik fungsi $f(x)$ dan $g(x)$ dengan menggunakan metode tabel seperti tampak pada gambar berikut.

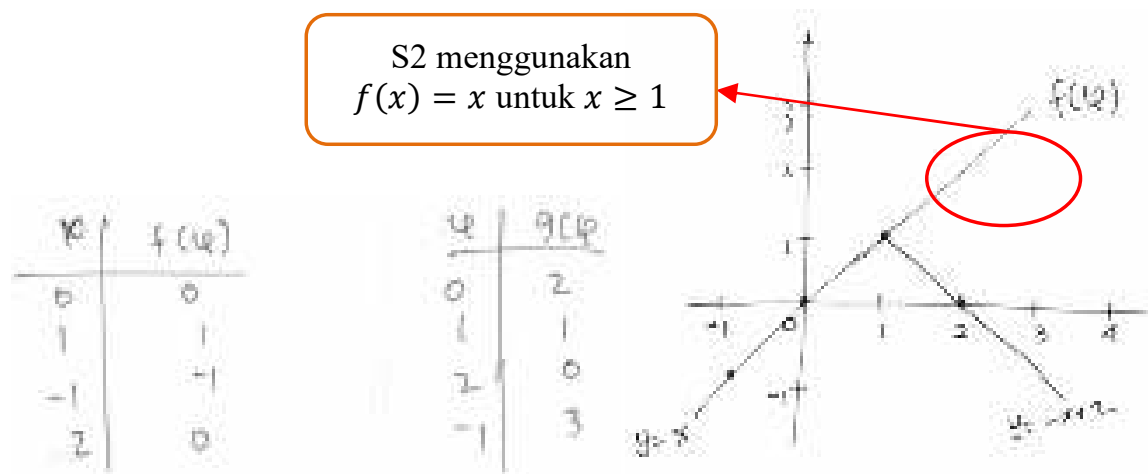

Gambar 10. Penyelesaian lembar tugas 1 ketika S2 menggambar grafik $f(x)$ dan $g(x)$ 


\section{Histogram: Jurnal Pendidikan Matematika, 4 (2), 2020 - 262 Imam Fahcruddin ${ }^{*}$, I Made Sulandra ${ }^{2}$}

Pada saat menggambar grafik $f(x)=-|x-1|+1$, S2 menggambar grafik fungsi $f(x)=$ $x$ untuk $x \geq 1$, padahal untuk $x \geq 1$, sesuai penjabaran fungsi bernilai mutlak seharusnya $f(x)=-x+2$, maka peneliti memberikan scaffolding berupa perintah untuk mereview kembali kesesuaian tabel yang dibuat dengan grafik yang digambar.

$\mathrm{P}$ : Perhatikan gambar grafik fungsi $f(x)$ dengan tabel yang kamu buat, apakah sudah sesuai?

S2: Tidak Pak.. karena untuk $x=2$ harusnya $y=0$, bukan 2

$\mathrm{P}$ : Baik, gambar lagi grafiknya.

Kemudian S2 menggambar kembali grafik fungsif $f(x)=-|x-1|+1$ dan $g(x)=-x+$ 2, kemudian mengarsir daerah yang dibatasi $f(x), g(x)$ dan sumbu y seperti gambar berikut.

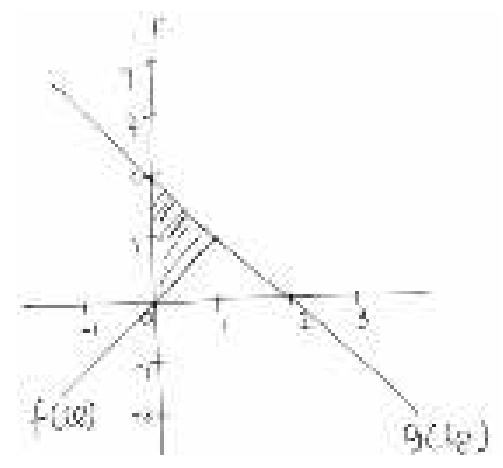

Gambar 11. Penyelesaian lembar tugas 1 ketika S2 menggambar grafik fungsi $f(x)$ dan $g(x)$ dan mengarsir daerah yang dibatasi fungsi $f(x), g(x)$ serta sumbu $y$

Selanjutnya S2 mengidentifikasi jari-jari cakram yang telah digambar. Namun, S2 melakukan kesalahan dalam mengidentifikasi jari-jari cakram tersebut. Hal ini terlihat ketika S2 menuliskan jari-jari cakram adalah $y_{i}=-x_{i}+2$ untuk $x_{i} \in[0,1]$. Padahal $y_{i}=$ $-x_{i}+2$, untuk $x_{i} \in[0,1]$ bukanlah jari-jari cakram melainkan tinggi cakram. Adapun penyelesaian S2 sebelum diberikan scaffolding disajikan dalam gambar berikut ini. 
Histogram: Jurnal Pendidikan Matematika, 4 (2), 2020 - 263 Imam Fahcruddin $^{1 *}$, I Made Sulandra ${ }^{2}$

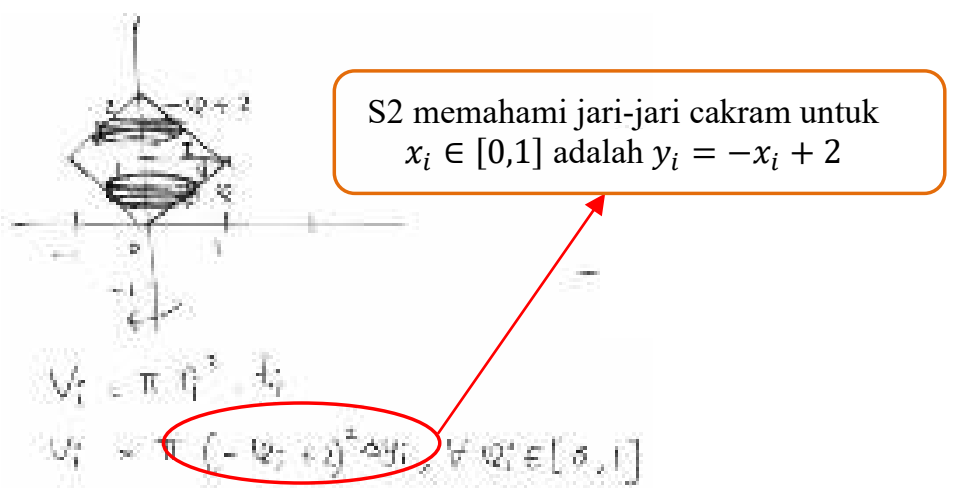

Gambar 12. Penyelesaian S2 ketika menentukan jari-jari cakram sebelum scaffolding

Kemudian proses scaffolding yang dilakukan peneliti adalah mengajak peserta didik untuk berkontribusi mencari petunjuk-petunjuk untuk mengerjakan soal, yaitu jari-jari cakram sebagai berikut.

P : Coba gambar lagi cakramnya, kemudian beri garis, jari-jari benda putarnya yang mana?

S2: Ini Pak.

$\mathrm{P}:$ Baik, apa benar jari-jarinya adalah $r_{i}=-x_{i}+2$ ?

S2: (lama mengamati cakram) Bingung saya Pak

$\mathrm{P}:$ Baik, sekarang posisi jari-jari ada dimana?

S2: Eee.. Disini Pak, Oh, iya Pak, ini jari-jarinya $x_{i}$

Akhirnya S2 memperbaiki hasil jawabannya seperti tampak pada gambar berikut.

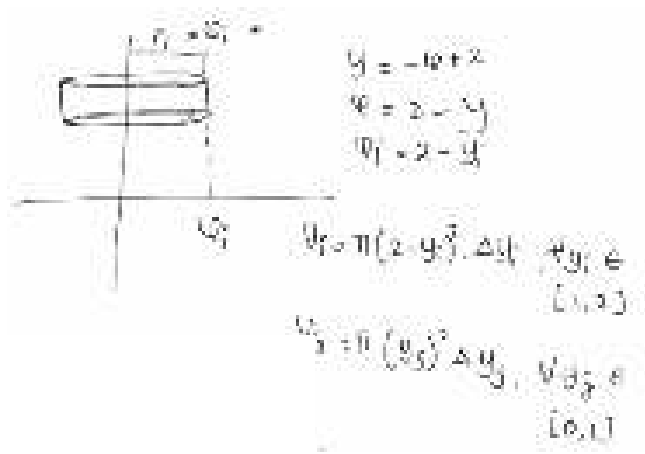

Gambar 13. Penyelesaian S2 ketika menentukan jari-jari cakram setelah proses scaffolding

Setelah itu, S2 berhenti mengerjakan karena bingung bagaimana memformulasikan volume benda putar. Akhirnya peneliti memberikan scaffolding kepada peserta didik dengan memberi penjelasan konsep yang digunakan untuk menghampiri volume benda putar.

$\mathrm{P}$ :Dari cakram yang kamu buat, dapat digunakan untuk menghampiri volume benda putar ini 


\section{Histogram: Jurnal Pendidikan Matematika, 4 (2), 2020 - 264 Imam Fahcruddin ${ }^{*}$, I Made Sulandra ${ }^{2}$}

S2: Bagaimana caranya Bapak?

$\mathrm{P}$ : Cakram-cakram ini dibuat sebanyak, kemudian semuanya dijumlahkan.

S2: Kemudian agar menjadi bentuk integral, bagaimana caranya Bapak?

$\mathrm{P}$ : Coba ingat kembali definisi integral?

S2: Oh, cakram dibuat sampai tak hingga Bapak, kemudian menggunakan limit $n$ menuju tak hingga, jadi dapat bentuk integral tentunya Pak.

Kemudian S2 memformulasikan bentuk integral tentu untuk lembar tugas 1 dengan metode cakram tanpa melakukan kesalahan.

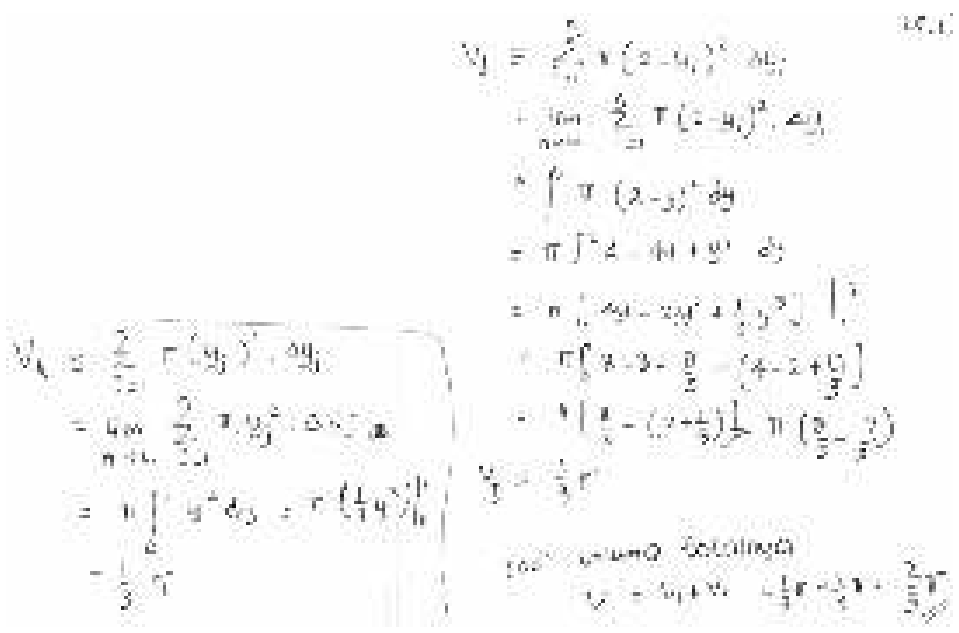

Gambar 14. Penyelesaian S2 ketika memformulasikan volume benda putar

Lebih lanjut, peneliti meminta S2 untuk mengerjakan lembar tugas 2. Keefektifan proses scaffolding ditunjukkan dengan tidak ditemukannya kesalahan-kesalahan yang dilakukan ketika mengerjakan lembar tugas. Penyelesaian S2 ketika mengerjakan lembar tugas 2 dengan metode yang berbeda dari lembar tugas 1 sudah benar. Hal ini menunjukkan bahwa melalui proses scaffolding yang peneliti lakukan sebelumnya dapat mengatasi kesalahan-kesalahan yang dialami S2 dalam menentukan volume benda putar.

\section{PROSES SCAFFOLDING S3}

Kemudian, jawaban S3 dalam menyelesaikan lembar tugas 1 sebelum proses scaffolding disajikan dalam gambar berikut.

S3 tidak dapat melanjutkan ke tahapan berikutnya dalam menentukan titik potong sumbu $x$ 
Histogram: Jurnal Pendidikan Matematika, 4 (2), 2020 - 265 Imam Fahcruddin ${ }^{1 *}$, I Made Sulandra ${ }^{2}$

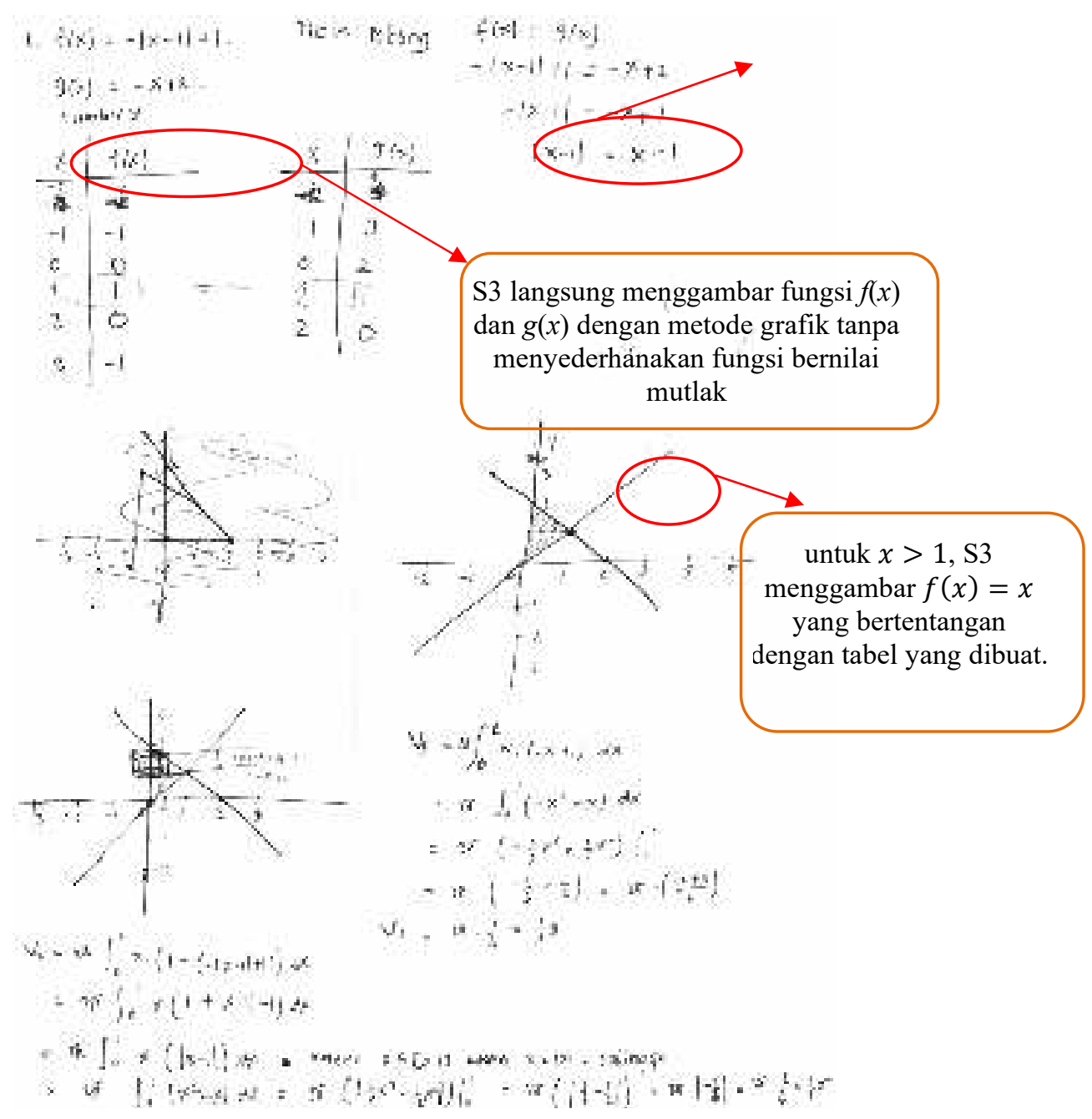

Gambar 15. Penyelesaian lembar tugas 1 oleh S3 sebelum proses scaffolding

Dalam penyelesaian lembar tugas 1, terlebih dahulu S3 memfokuskan diri untuk membuat tabel fungsi $f(x)$ dan $g(x)$. S3 tidak memulai dengan menyederhanakan fungsi bernilai mutlak. Lebih lanjut, S3 tidak menentukan volume irisan benda putar yang digunakan untuk menghampiri volume benda putar. Hal ini menyebabkan S3 tidak dapat merencanakan masalah dengan lengkap.

Dari hasil wawancara disimpulkan S3 kurang memahami definisi fungsi bernilai mutlak. S3 mampu menentukan bentuk integral dengan benar namun tidak dapat menjelaskan bagaimana kaitan antara kulit tabung yang ia gambar sehingga memperoleh bentuk integral tentu yang merepresentasikan volume benda putar. Hal ini mengindikasikan S3 melakukan kesalahan dalam memformulasikan volume benda putar dengan menggunakan integral tentu. 


\section{Histogram: Jurnal Pendidikan Matematika, 4 (2), 2020 - 266 Imam Fahcruddin ${ }^{*}$, I Made Sulandra ${ }^{2}$}

Kemudian peneliti meminta S3 untuk menyederhanakan fungsi bernilai mutlak $f(x)$, namun S3 berhenti mengerjakan ketika menyederhanakan fungsi bernilai mutlak $f(x)$. S3 berusaha memikirkan bagaimana menyederhanakan fungsi tersebut. Karena pada saat wawancara S3 menyatakan kesulitan dalam menyederhanakan fungsi bernilai mutlak, maka proses scaffolding yang diberikan berupa memverifikasi dan mengklarifikasi pemahaman peserta didik tentang konsep fungsi bernnilai mutlak.

$\mathrm{P}:$ Tulislah definisi fungsi bernilai mutlak $|x|$ ?

S3: Baik bapak (S3 mampu menyederhanakan $|x|$ dengan benar).

$\mathrm{P}:$ Nah, sekarang dengan menggunakan cara yang sama, sederhanakan fungsi $f(x)=-|x-1|+1$.

S3: Baik Pak. (S3 membagi kasus menjadi dua, yaitu $x \geq 0$ dan $x<0$ )

$\mathrm{P}$ : Sekarang perhatikan hasil penyederhanaan ini, apakah sudah sesuai dengan definisinya?

S3 : Sesuai Bapak (S3 yakin bahwa jawaban yang dituliskan benar)

$\mathrm{P} \quad$ : Silahkan dicermati kembali

S3 : Sudah Pak, ini hasil penyederhanaannya

$\mathrm{P}:$ : Sekarang perhatikan hasil penyederhanaan $|x|$, kenapa dibagi menjadi dua kasus, $x \geq 0$ dan $x<0$ ?

S3 : Karena fungsi yang ada dalam tanda mutlak adalah $x$ Pak, kemungkinannya bisa lebih dari sama dengan nol atau kurang dari nol, Oh, Iya Pak, yang dimutlakkan $x-1$, jadi kemungkinannya $x-1 \geq 0$ atau $x-1<0$.

$\mathrm{P} \quad$ : Baik, silahkan diperbaiki

Akhirnya S3 memperbaiki hasil jawabannya seperti tampak pada gambar berikut.

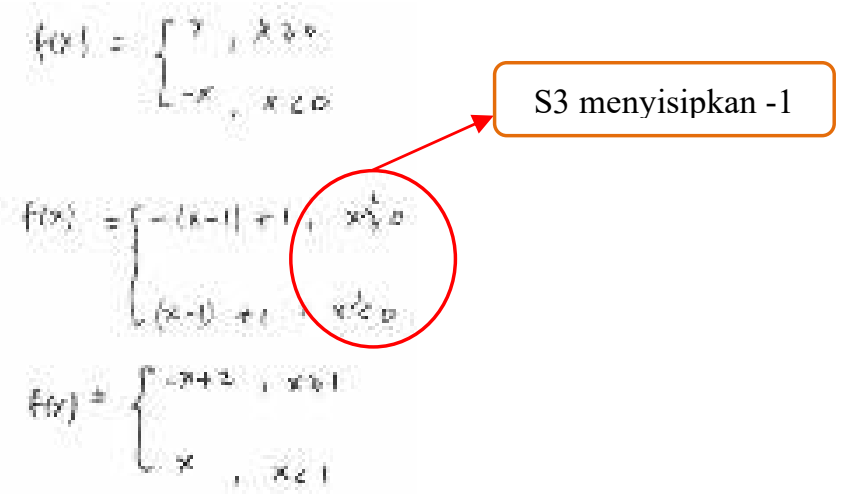

Gambar 16. Penyelesaian S3 menyederhanakan fungsi bernilai mutlak $f(x)$ setelah scaffolding

Kemudian S3 menentukan titik koordinat fungsi $f(x)$ dan $g(x)$ dengan metode grafik lalu menghubungkan titik-titik tersebut dengan garis. Selain itu S3 juga mengarsir daerah yang dibatasi fungsi $f(x), g(x)$ dan sumbu y serta menggambar kulit tabung pada daerah yang diarsir. S3 mengidentifikasi tinggi kulit tabung dengan memberi garis yang 


\section{Histogram: Jurnal Pendidikan Matematika, 4 (2), 2020 - 267 Imam Fahcruddin $^{1 *}$, I Made Sulandra ${ }^{2}$}

merepresentasikan tinggi kulit tabung lalu menuliskan tinggi kulit tabung adalah $t=$ $-x_{i}+2-\left(x_{i}\right)$. Adapun penyelesaian dalam menggambar kulit tabung disajikan pada gambar berikut.

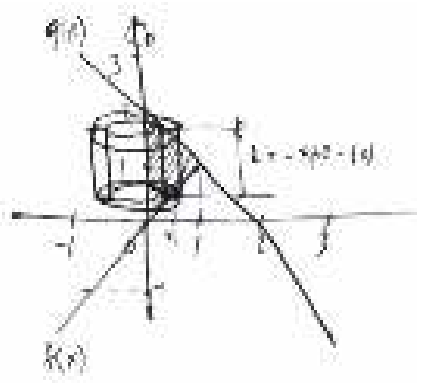

Gambar 17. Penyelesaian masalah nomor 1 ketika S3 menggambar kulit tabung

Pada saat memformulasikan benda putar, S3 menggunakan metode kulit tabung karena benda putar yang ia gunakan untuk menghampiri volume benda putar berbentuk kulit tabung. Namun, S3 tidak dapat menjelaskan bagaimana menggunakan kulit tabung untuk menghampiri volume benda putar. Adapun proses scaffolding yang dilakukan peneliti adalah mengajak peserta didik untuk berkontribusi mencari petunjuk-petunjuk untuk mengerjakan soal sebagai berikut.

$\mathrm{P}$ : Bagaimana menggunakan kulit tabung tersebut untuk menghampiri volume benda putar secara keseluruhan?

S3 : Kulit tabung dibuat semakin banyak Bapak, kemudian masing-masing kulit tabung dijumlahkan.

$\mathrm{P}$ : Nah, Bagaimana menuliskannya?

S3 : Menggunakan konsep sigma Bapak, kalau kulit tabungnya dibuat sampai $n$, berarti batas atas sigma nya $n$.

Akhirnya S3 memperbaiki jawabannya seperti tampak pada gambar berikut.

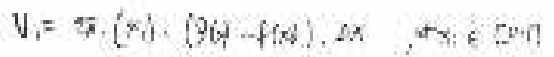

$$
\begin{aligned}
& V_{i}=\pi x_{i}\left(-x_{i+2}-x_{i}\right) \Delta x_{i} \\
& \left.v=\sum_{i=i}^{n} a x_{i}\left(-2 x_{1}+2\right) . \Delta x_{i}, \forall x_{i}<\left[a_{1}\right]\right] \\
& V=\operatorname{Lim}_{n \rightarrow 4} \sum_{i=1}^{n} i \pi x_{i}\left\langle-2 f_{i}+1\right) d x_{i} \\
& =\int_{0}^{1} x(x)(x+2) d x \\
& =2 \pi \int_{3}^{1}-2 x^{2}+2 x d x=\left.\pi\left[-\frac{1}{3} x^{3}+x^{3}\right\}\right|_{0} ^{1} \\
& V=\pi\left(\frac{-1}{3}+1\right)=2 \cdot\left(-\frac{14}{3}\right)=\frac{1}{3} \pi \cdot \pi \text {. }
\end{aligned}
$$

Gambar 18. Penyelesaian S3 ketika memformulasikan volume benda putar 


\section{Histogram: Jurnal Pendidikan Matematika, 4 (2), 2020 - 268 Imam Fahcruddin ${ }^{*}$, I Made Sulandra ${ }^{2}$}

Lebih lanjut, peneliti meminta S3 untuk mengerjakan lembar tugas 2. Keefektifan proses scaffolding ditunjukkan dengan tidak ditemukannya kesalahan-kesalahan yang dilakukan S3 ketika mengerjakan lembar tugas 2. S3 diharapkan mampu memahami masalah secara lengkap dan membuat perencanaan dengan baik serta melaksanakan rencana dengan benar sehingga memperoleh jawaban yang benar.

\section{KESIMPULAN DAN SARAN}

\section{A. Kesimpulan}

Berdasarkan hasil dan pembahasan diperoleh kesimpulan bahwa scaffolding yang diberikan kepada peserta didik yang mengalami kesalahan dalam menyederhanakan fungsi bernilai mutlak adalah memberikan stimulus berupa pertanyaan yang mengarahkan untuk mengingat dan menjelaskan definisi fungsi bernilai mutlak. Kemudian, scaffolding yang diberikan kepada peserta didik yang mengalami kesalahan dalam memformulasikan volume benda putar adalah memberikan pertanyaan untuk mengingat kembali konsepkonsep yang digunakan dalam memformulasikan volume benda putar. Selanjutnya, scaffolding yang diberikan kepada peserta didik yang mengalami kesalahan dalam menentukan daerah yang dibatasi beberapa fungsi adalah mengajak peserta didik untuk berkontribusi mencari petunjuk-petunjuk dalam menentukan daerah yang dibatasi beberapa fungsi.

\section{B. Saran}

Penelitian ini hanya mengkaji proses scaffolding yang diberikan kepada peserta didik berdasarkan kesalahan-kesalahan yang dialami ketika menyelesaikan masalah integral tentu pada volume benda putar. Dalam pemecahan masalah volume benda putar, fungsi yang digunakan melibatkan fungsi bernilai mutlak. Oleh karena itu, perlu dikaji dari sudut pandang penyampaian materi oleh pendidik yang menyebabkan peserta didik tidak dapat menyelesaikan masalah penerapan integral tentu pada volume benda putar dengan benar.

\section{DAFTAR PUSTAKA}

Anghileri, J. (2006). Scaffolding Practices that Enhance Mathematics Learning. Journal of Mathematics Teacher Education. 9. Page 33-52.

Asmana, A. T. (2018). Profil komunikasi matematika tertulis dalam pemecahan masalah matematika di smp ditinjau dari kemampuan matematika. INSPIRAMATIKA, 3(1), $1-12$.

Batanero, C., Godino, D. J., Vallecillos, A., Green, D. R. \& Holmes, P. (2009). Errors and difficulties in understanding elementary statistical concepts. International Journal of Mathematics Education in Science and Technology. 25 (3). Page 527 - 537. 


\section{Histogram: Jurnal Pendidikan Matematika, 4 (2), 2020 - 269 Imam Fahcruddin ${ }^{1 *}$, I Made Sulandra ${ }^{2}$}

Bikmaz, Fatma H., Celebi, O., Ata, A., Ozer, E., Soyak, O., \& Recber, Hande. (2010). Scaffolding Strategies Applied by Student Teachers to Teach Mathematics. The International Journal of Research in Teacher Education.Vol. 1. ISSN: 1308-951X. Page: 25-36.

Hartman, H. (2002). Scaffolding and Co-operative Learning: Human Learning and Instruction. New York: College of City University Press.

Fahcruddin, I., Salmah, S., \& Malau, A. G. (2019). Optimal Control For Malaria Epidemic Model With Vaccinating, Human Treatment And Mosquitos Spraying. Selecciones Matemáticas, 6(02), 189-195.

Fahcruddin, I. (2011). Positifitas dan Ketercapaian Sistem Linier Fractional Waktu Kontinu. CAUCHY, 2(1), 18-23.

Krulik, S., Rudnic, J. A. \& Milou, E. (2003). Teaching Mathematics in Middle School. Boston: Pearson Education Inc.

Kereh, Cicylia Triratna, Sabandar J., \& Tjiang, Paulus C. (2013). Identifikasi Kesalahan Belajar Peserta didik dalam Konten Matematika pada Materi Pendahuluan Fisika Inti. Prosiding Seminar Nasional Sains dan Pendidikan Sains VIII. Fakultas Sains dan Matematika UKSW Salatiga. Vol. 3. No. 1. ISSN:2087-0922

Mofolo-Mbokane, B., Engelbrecht, J., \& Harding, A. (2013). Learning difficulties with solids of revolution: classroom observations. International Journal of Mathematical Education in Science and Technology (IJMEST). London: Taylor \& Francis.

Polya, G. (1973). How to Solve it. Princeton: Princeton University Press.

Reknati, P. (2019). Implementasi Sistem Penjamin Mutu Internal dalam Meningkatkan Mutu di Sekolah Tinggi Ilmu Pelayaran. Meteor STIP Marunda, 12(1), 73-81.

Suardipa, I. P. (2020). Proses Scaffolding Pada Zone Of Proximal Development (ZPD) dalam Pembelajaran. Widyacarya: Jurnal Pendidikan, Agama dan Budaya, 3(1), 7992.

Sugiman. (2013). Student's Competency in Solving and Creating Mathematical Problem in Pre-Service Training Program. Jurnal Teknologi. Malaysia: UTM.

Wibawa, K. A., Nusantara, T., Subanji, S., \& Parta, I. N. (2018). Defragmentasi Pengaktifan Skema Mahasiswa Untuk Memperbaiki Terjadinya Berpikir Pseudo Dalam Memecahkan Masalah Matematis. Prima: Jurnal Pendidikan Matematika, 2(2), 93-105.

Yohanes, Rudi Santoso. (2010). Teori Vygotsky dan Implikasinya terhadap Pembelajaran Matematika. Jurnal Ilmiah Widya Warta. No. 2. ISSN 0853-1981.

Yin, R.K. (2011). Qualitative Research from Start to Finish. New York: The Guilford Press. 